\title{
The Effect of Chronic Inhouse Biomass Fuel Smoke Exposure on Coronary Slow Flow Phenomenon in Women Living in the Eastern Region of Turkey
}

\section{Kronik Ev Içi Biyolojik Yakıt Dumanına Maruz Kalmanın Türkiye'nin Doğu Bölgesinde Yaşayan Kadınlarda Koroner Yavaş Akım Fenomeni Üzerine Etkisi}

\author{
(D) Tayyar AKBULUT, (D) Faysal SAYLIK
}

University of Health Sciences Turkey, Van Training and Research Hospital, Clinic of Cardiology, Van, Turkey

\begin{abstract}
Objective: Biomass fuel (BMF) is still widely used in rural areas for cooking and heating worldwide. BMF smoke inhalation is a prominent cause of respiratory and cardiovascular disease. The slow coronary flow (SCF) phenomenon is known as the delayed opacification of distal coronary arteries on a coronary angiogram. SCF is known to be related to cardiovascular morbidity and mortality. Thus, we aimed to investigate the relationship between exposure to BMF and SCF in women in this study. Methods: A total of 457 consecutive women who underwent coronary angiography were retrospectively enrolled in this study. Patients were divided into two groups according to the use of BMF during their lives, from birth to older ages, as biomass exposure group (BEG) and non-exposure group. The presence of SCF was calculated based on thrombolysis in myocardial infarction frame count.

Results: Two hundred fifty nine patients were in the BEG, whereas 198 patients were in the non-exposure group. The prevalence of SCF was higher in the BEC compared to the non-exposure group $(47.9 \%$ vs $13.1 \%$, respectively, $\mathrm{p}<0.001)$. The presence of biomass exposure, body mass index, white blood cell count, low-density lipoprotein cholesterol C-reactive protein, serum creatinine, and hypertension were independent predictors of SCF. The optimal cutoff point of biomass exposure time in years to detect the presence of SCF was 30 years (Area under the curve: 0.71 , sensitivity: 0.65 , specifity: 0.71 )

Conclusions: Exposure to indoor BMF was associated with a SCF phenomenon in women.

Keywords: Biomass fuel exposure, slow coronary flow phenomenon indoor air pollution
\end{abstract}

\section{öz}

Amaç: Biyokütle yakıtı (BY), dünya genelinde kırsal kesimlerde yemek pişirmek ve ısınmak için halen yaygın olarak kullanılmaktadır. BY dumanının solunması, solunum ve kardiyovasküler hastalıkların önemli bir nedenidir. Koroner yavaş akım (KYA) fenomeni, koroner anjiyogramda uç koroner arterlerin gecikmiş opaklaşması olarak bilinmektedir. KYA'nın, kardiyovasküler morbidite ve mortalite ile ilişkili olduğu bilinmektedir. Bu nedenle, biz bu çalışmada kadınlarda BY'ye maruz kalma ile KYA arasındaki ilişkiyi araştırmayı amaçladık. Yöntemler: Bu çalışmaya koroner anjiyografi yapılmış olan toplam 457 ardışık kadın retrospektif olarak alındı. Hastalar, doğumdan ileri yaşlarına kadar yaşamları boyunca BY kullanımlarına göre hayvansal maruziyet grubu (HMG) ve maruz kalmayan grup olmak üzere iki gruba ayrıldı. KYA varlığı, miyokard enfarktüsünde trombolizis kare sayısına göre hesaplandı.

Bulgular: HMG'de 259 hasta varken, maruz kalmayan grupta 198 hasta vardı. KYA prevalansı HMG'de maruz kalmayan gruba kıyasla daha yüksekti (sırasıyla \%47,9'a karşı \%13,1, p<0,001). HY'ye maruz kalma varlığı, vücut kitle indeksi, beyaz kan hücre sayısı, düşük yoğunluklu lipoprotein kolesterol, C-reaktif protein, serum kreatinin ve hipertansiyon, KYA'nın bağımsız öngörücüleriydi. KYA varlığın saptamak için yıl cinsinden biyokütle maruziyet süresinin optimal kesme noktası 30 yıl idi (Eğrinin altındaki alan: 0,7l, duyarlılık: 0,65 özgüllük: 0,71).

Sonuçlar: Ev içi BY'ye maruz kalma, kadınlarda KYA fenomeni ile ilişkiliydi.

Anahtar kelimeler: Hayvansal biyokütle yakıt maruziyeti, koroner yavaş akım fenomeni, oda içi hava kirliliği
Address for Correspondence: F. Saylik, University of Health Sciences Turkey, Van Training and Research Hospital, Clinic of Cardiology, Van, Turkey

E-mail: faysalsaylikegmail.com ORCID ID: orcid.org/0000-0003-3165-6769
Received: 13 October 2021

Accepted: 20 January 2022

Online First: 01 February 2022

Cite as: Akbulut T, Saylik F. The Effect of Chronic Inhouse Biomass Fuel Smoke Exposure on Coronary Slow Flow Phenomenon in Women Living in the Eastern Region of Turkey. Medeni Med J 2022;37:21-28

${ }^{\circledR}$ Copyright 2022 by the Istanbul Medeniyet University / Medeniyet Medical Journal published by Galenos Publishing House.

Licenced by Creative Commons Attribution-NonCommercial 4.0 International (CC BY-NC 4.0) 


\section{INTRODUCTION}

Biomass fuel (BMF) is referred to as animal and plant material and is used as the primary source of domestic energy for heating and cooking in developing and lowincome countries'. A large part of rural people of eastern Turkey use dried animal dung, which is a kind of BMF. When BMF is burned in an open fire or a traditional stove inefficiently, large amounts of particulate matter (PM), hydrocarbons, free radicals, oxygenated and chlorinated organics, and as well as carbon monoxide can be generated and easily inhaled ${ }^{2}$. The inhalation of those materials from birth to older age has been linked to an increased risk of chronic obstructive pulmonary disease (COPD), interstitial lung disease, asthma, lower respiratory tract infections, tuberculosis, lung cancer, cataract, and blindness ${ }^{3-6}$. Previous studies have investigated the effects of exposure to BMF on the cardiovascular system. It has been reported that BMF is associated with endothelial inflammation and endothelial dysfunction ${ }^{1,7}$, elevated blood pressure and hypertension $(\mathrm{HT})^{8}$, coronary artery disease ${ }^{9}$, stroke, and sudden cardiac death ${ }^{10,11}$.

Slow coronary flow (SCF) phenomenon is defined as delayed epicardial coronary artery opacification on selective coronary angiography in the absence of coronary artery stenosis and/or myocardial bridge. It was first defined by Tambe et al..$^{2}$ and was considered as an important clinical entity over time. The prevalence of SCF was reported within a range of $0.2 \%$ to $24 \%$ in the previous cohort studies ${ }^{13}$. Although the underlying mechanism has not been fully understood yet, the micro and macrovascular endothelial dysfunction of the epicardial coronary arteries and inflammation are accepted as the main pathophysiological mechanisms ${ }^{14,15}$. The SCF is related to recurrent chest pain, which is characterized as unstable angina ${ }^{14}$. Sudden cardiac death was reported in a few patients who had $\mathrm{SCF}^{16,17}$. Because biomass exposure led to endothelial dysfunction, which was considered the main underlying pathologic cause of SCF, we aimed to investigate the association of chronic inhouse biomass exposure with SCF in this study.

\section{MATERIALS and METHODS}

A total of 457 consecutive female patients who underwent coronary angiography were recruited in this retrospective observational study. Due to the fact that women had more frequent daily exposure to BMF inhalation than men (cooking, indoor work, childcare) and because men did not have exposure to biomass, especially for cooking, male patients were not included in this study. The exclusion criteria were as follows; acute coronary syndrome, mild, moderate, and significant coronary artery occlusion, history of previous revascularization, coronary ectasia, renal or hepatic failure, acute or chronic infection, active inflammation, decompensated heart failure, moderate or severe valvular heart disease, anemia, cigarette smoking, malignancy, and hematologic disorders. The Van Training and Research Hospital Clinical Research Ethics Committee approved the study, and the research was done in accordance with the Declaration of Helsinki (decision no: 2020/20, date: 08.10.2020).

The biomass exposure group (BEG) was living in the villages of Van, which was a rural area in the east of Turkey. They had been exposed to biomass smoke inhalation from birth to adulthood by inhaling dried animal dung for heating in all days of autumn and winter months and from adulthood to old age for heating and cooking in all days of the year. The main BMF was dried animal dung in our study group. The median time of biomass exposure was 29 years in the BEG [interquartile range (IQR) $=20-38$ years]. The control group was living in the center of Van, and they were not using BMF for cooking or heating. All of the patients in the control group were born and living in the city, and they used central heating systems using coal or liquid gases and used liquid gases for cooking all their lives.

\section{Coronary Angiography}

Coronary angiography was performed in all patients with positive noninvasive test results or high clinical suspicion for coronary artery occlusion via radial or femoral approach using the Judkins technique. Patients with high blood pressure during the procedure were not included in the study due to the risk of misdiagnosis of SCF. The angiographic images of the coronary arteries were taken by using a digital angiographic system (AXIOM Artis, Siemens AG, Munich, Germany) using iopromide (Omnipaque, GE Healthcare, Cork, Ireland) as a contrast agent.

The number of cine frames obtained from all patients at $30 \mathrm{frames} / \mathrm{s}$ required for the contrast to first reach the standard distal coronary landmark in the left anterior descending (LAD) artery, left circumflex (CX) artery, and right coronary artery (RCA) was used to calculate thrombolysis in myocardial infarction frame count (TFC). The distal landmark for the coronary arteries was described as follows; distal bifurcation for the LAD, distal bifurcation of the major branch of the CX or main CX, whichever was longer for the CX artery, and the first branch of the posterolateral artery for the RCA, regardless of the size of this branch. Due to the LAD being generally longer than other epicardial coronary arteries, 
corrected TFC was calculated by dividing TFC by 1.7 for the LAD artery. Finally, SCF was defined in patients who had a TFC count higher than two standard deviations from the normal range for at least one of the coronary arteries (36.2 \pm 2.6 frames for the LAD, 22.2 \pm 4.1 frames for the CX, and $20.4 \pm 3$ frames for the RCA $)^{18}$.

\section{Laboratory Measurements}

All blood samples were taken from the antecubital vein of patients on the day of admission to the cardiology clinic. A Beckman Coulter LH 780 hematology analyzer (Beckman Coulter, FL, USA) was used for hematologic parameter measurements, and a Beckman Coulter LH 780 device (Beckman Coulter Ireland Inc., Mervue, Galway, Ireland) was used for biochemical parameters.

\section{Definitions}

HT was determined as systolic blood pressure $\geq 140$ $\mathrm{mmHg}$ and/or diastolic blood pressure $\geq 90 \mathrm{mmHg}$ at least two times or in the presence of using current antihypertensive drugs. Diabetes mellitus was diagnosed according to fasting glucose $\geq 126 \mathrm{mg} / \mathrm{dL}$ or postprandial glucose $\geq 200 \mathrm{mg} / \mathrm{dL}$ or when there was use of antidiabetic drugs. Dyslipidemia was diagnosed according to total cholesterol level of $>240 \mathrm{mg} / \mathrm{dL}$, low-density lipoprotein (LDL) cholesterol level of $>130 \mathrm{mg} / \mathrm{dL}$, serum triglycerides $>200 \mathrm{mg} / \mathrm{dL}$ and/or when there was use oflipid-lowering drugs. The body mass index (BMI) was calculated using the formula $\mathrm{BMI}=$ weight $(\mathrm{kg}) /$ height $(\mathrm{m})^{2}$.

\section{Statistical Analysis}

All statistical analyses were done with R-software v. 3.6.3 (R statistical software, Institute for Statistics and Mathematics, Vienna, Austria). To determine normality, the Kolmogorov-Smirnov test was performed. Based on normality, continuous variables with a normal distribution were denoted as the arithmetical mean (standard deviation), and variables without a normal distribution were represented as median (IQR). The numbers and percentages were used to present categorical variables. The independent Student's t-test and Mann-Whitney $U$ tests were performed to compare continuous variables. The chi-square test or Fisher's Exact test was used to compare categorical variables, as appropriate. A Spearman correlation was used to assess the relationship between TFC and exposure time to BMF. A univariate logistic regression analysis was used to detect the associations of variables with SCF. A multivariable logistic regression analysis with variables that had a $p$-value $<0.2$ in univariate logistic regression analysis was used to detect independent predictors of SCF in the study population. A receiver operating characteristic curve was used to establish the best cutoff value of the biomass exposure time to detect the SCF by calculating the Youden index. A 2-sided $p<0.05$ was considered statistically significant.

\section{RESULTS}

A total of 457 patients (259 patients in the BEG and 198 patients in the control group) were enrolled in this retrospective observational study. $\mathrm{BMI}$, the frequency of COPD, white blood cell (WBC), and LDL levels were higher in the BEG when compared to the control group. There were no differences between groups regarding other demographic, clinic, and laboratory features. The BEG had higher rates of SCF than the control group ( $47.9 \%$ vs. $13.1 \%, p<0.001$, respectively) (Table 1, Figure 1). There was no statistically significant difference in the rate of SCF between patients who had last used biomass ${ }^{3} 10$ years ago and those who had used $<10$ years $(45.5 \%$ vs. $48.5 \%$, respectively, $\mathrm{p}$-value $=0.825$ ).

Table 2 summarizes the univariate and multivariate logistic regression analysis results. In univariate logistic regression analysis, BMI, COPD, WBC, LDL cholesterol, $C$-reactive protein (CRP), serum creatinine level, the presence of HT, and biomass exposure were associated with the SCF. Multivariable logistic regression analysis revealed that $B M I, W B C$, LDL cholesterol, CRP, serum creatinine level, the presence of $\mathrm{HT}$, and biomass exposure were independent predictors of SCF. Exposure to BMF inhalation had an 8.5 fold enhanced risk of SCF compared to the control group $(p<0.001)$. The best cutoff value of the biomass exposure time to detect SCF was 30 years, with a sensitivity of $65 \%$ and a specificity of $71 \%$ (Figure 2). The Spearman correlation analysis revealed

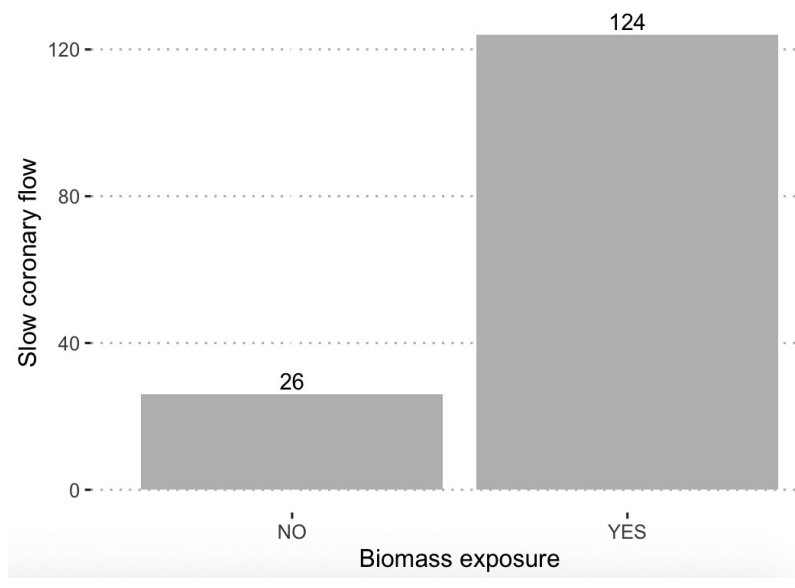

Figure 1. The frequency rates of slow coronary flow phenomenon between biomass fuel smoke exposure and non-exposure groups. 


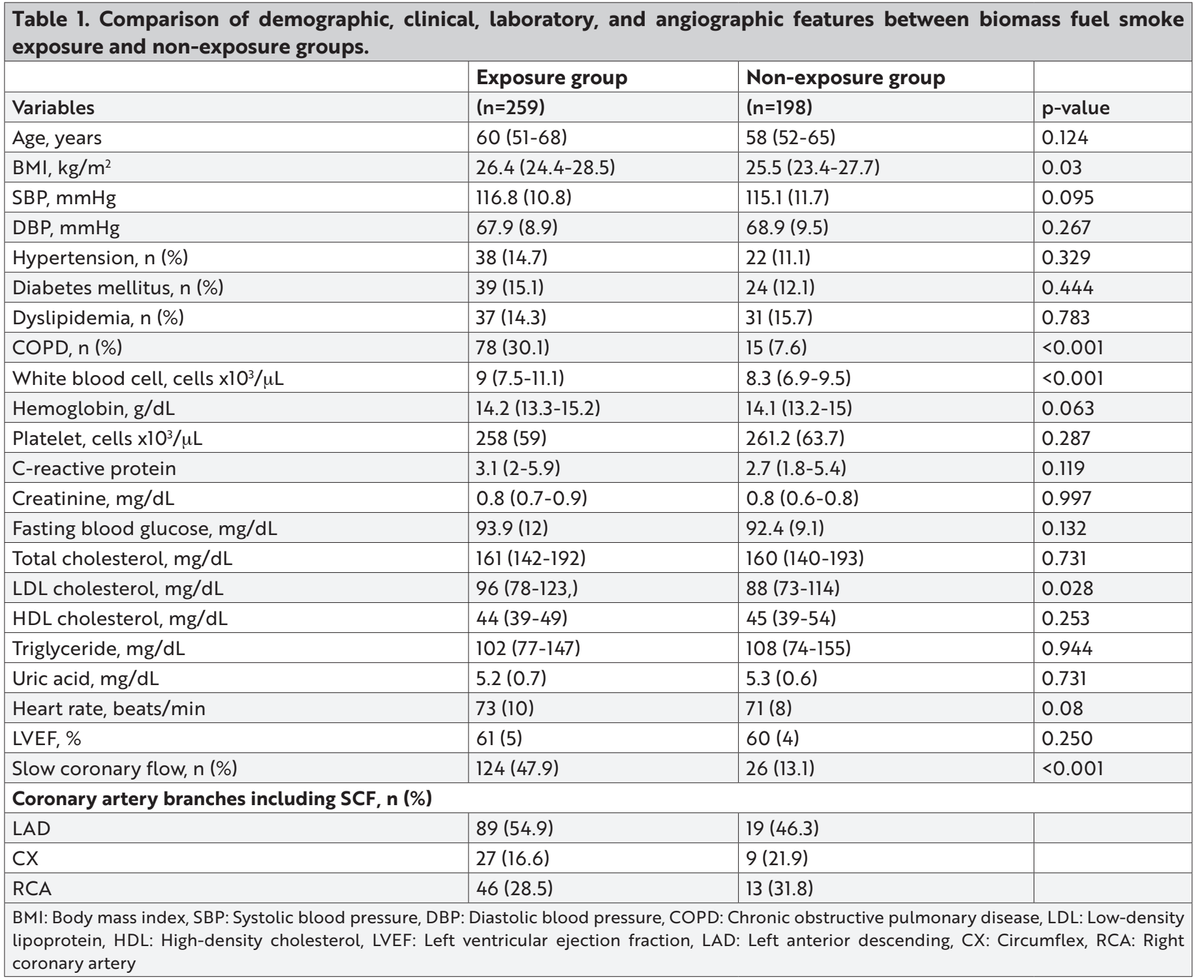

a moderate correlation between TFC and the exposure time to BMF in the study population $(R=0.3, p<0.001)$ (Figure 3).

\section{DISCUSSION}

This study showed that female patients who had exposure to BMF inhalation had more frequent SCF on their coronary angiograms. BMF exposure was an independent predictor of SCF in women patients who had used dried animal dung during their lives for cooking and heating.

The BMF (wood, crop waste, and coal, charcoal, and animal dung) is used in approximately $40 \%$ of households for cooking and heating in open fires or traditional stoves and causes higher indoor air pollution in developing countries $^{19}$. It has been estimated that indoor air pollution due to using BMF causes 3.8 million premature deaths per year, as declared by the World Health Organization ${ }^{20}$. Previous researches have investigated the effect of BMF use on the cardiovascular system. Inhalation of BMF was detected as an independent risk factor for cardiovascular morbidity and mortality ${ }^{21}$. Buturak et al.' found endothelial dysfunction in adults who had chronic exposure to animal dung inhalation, with lower flowmediated dilatation and endothelium-independent dilatation in the exposure group compared to the control group ( $5 \%$ vs. $11 \%$ and $14 \%$ vs. $22 \%$, respectively). In this study, the authors could not find a significant difference between the exposure and non-exposure groups regarding carotid intima-media thickness (CIMT), which was accepted as a marker of subclinical atherosclerosis. In contrast to that study, Painschab et al. ${ }^{22}$ discovered that BMF-inhalated patients had a higher prevalance of 
T. Akbulut and F. Saylik. Biomass Smoke and Slow Coronary Phenomenon

\begin{tabular}{|c|c|c|c|c|}
\hline & Univariate OR & & Multivariate OR & \\
\hline Variables & $(95 \% \mathrm{CI})$ & $\mathrm{p}$-value & $(95 \% \mathrm{Cl})$ & p-value \\
\hline Body mass index & 1.091 (1.044-1.142) & 0.001 & 1.117 (1.054-1.185) & 0.001 \\
\hline COPD & $1.742(1.175-2.577)$ & $<0.001$ & $1.062(0.634-1.773)$ & 0.845 \\
\hline White blood cell & 1.269 (1.190-1.358) & $<0.001$ & 1.138 (1.059-1.233) & 0.004 \\
\hline Hemoglobin & $1.129(0.999-1.280)$ & 0.106 & $0.823(0.689-0.981)$ & 0.069 \\
\hline Fasting blood glucose & $1.009(0.994-1.024)$ & 0.312 & - & - \\
\hline LDL cholesterol & 1.014 (1.009-1.019) & $<0.001$ & $1.010(1.003-1.018)$ & 0.029 \\
\hline C-reactive protein & $1.246(1.157-1.344)$ & $<0.001$ & $1.190(1.080-1.312)$ & 0.003 \\
\hline Serum creatinine & $1.583(1.408-1.788)$ & $<0.001$ & 1.631 (1.394-1.920) & $<0.001$ \\
\hline Platelet & 0.997 (0.994-1.000) & 0.103 & $0.998(0.993-1.001)$ & 0.123 \\
\hline Heart rate & $0.984(0.967-1.001)$ & 0.132 & 0.989 (0.966-1.011) & 0.433 \\
\hline Age & $1.006(0.992-1.020)$ & 0.467 & - & - \\
\hline Dyslipidemia & $1.531(0.978-2.380)$ & 0.113 & $0.719(0.348-1.466)$ & 0.451 \\
\hline Hypertension & $5.701(3.517-9.453)$ & $<0.001$ & 7.001 (3.673-13.902) & $<0.001$ \\
\hline Diabetes mellitus & $1.208(0.752-1.914)$ & 0.502 & - & - \\
\hline SBP & 1.017 (1.002-1.032) & 0.061 & $1.012(0.993-1.032)$ & 0.273 \\
\hline LVEF & $1.016(0.981-1.052)$ & 0.451 & - & - \\
\hline Biomass exposure & 6.076 (4.105-9.191) & $<0.001$ & $8.520(5.128-14.623)$ & $<0.001$ \\
\hline
\end{tabular}

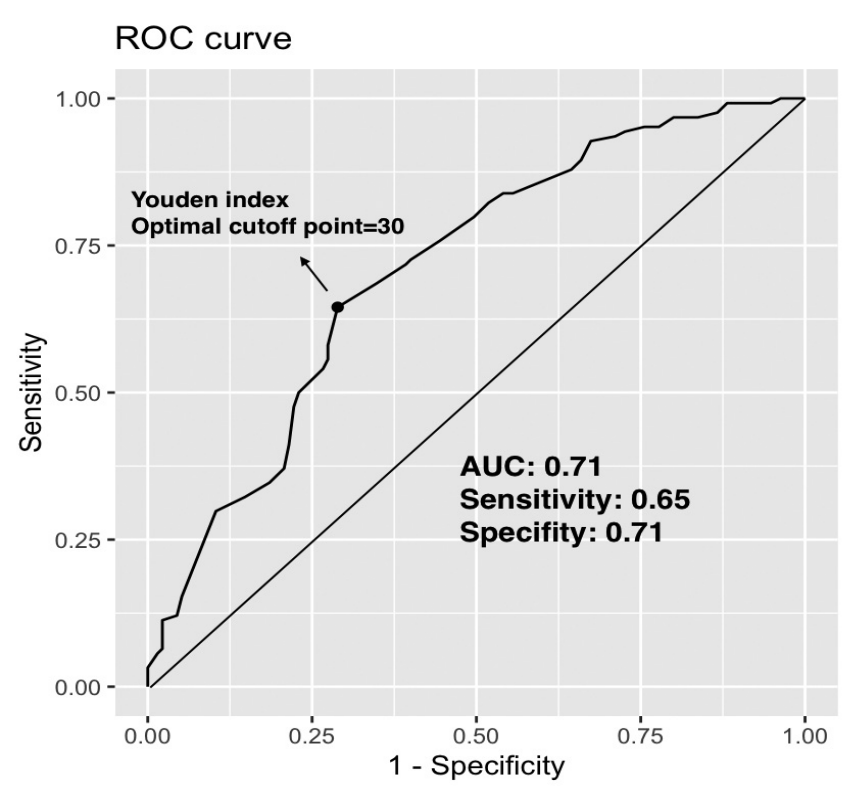

Figure 2. Receiver operating characteristics curve of biomass fuel smoke exposure time to detect slow coronary flow phenomenon.

ROC: Receiver operating characteristics, AUC: Area under the curve

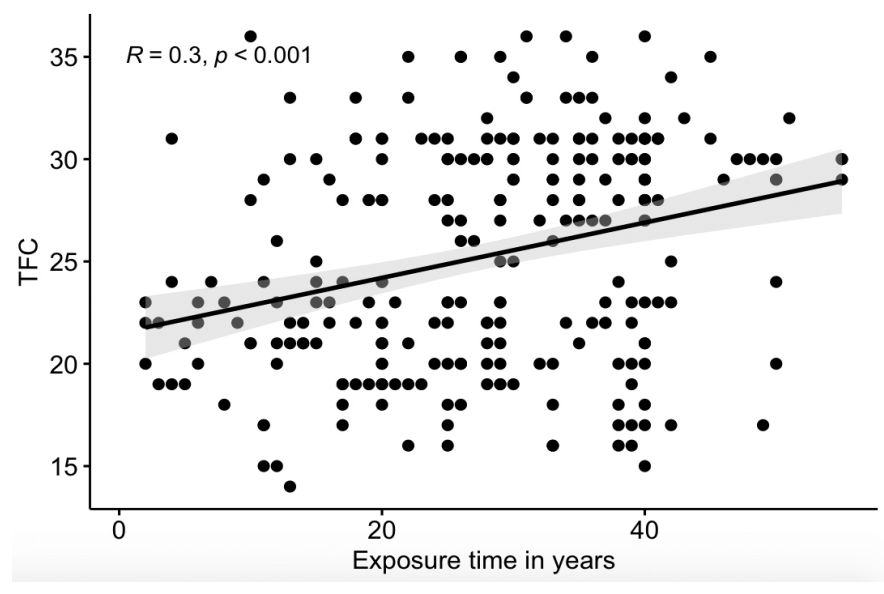

Figure 3. Correlation graph of thrombolysis in myocardial infarction frame count with biomass exposure time.

TFC: Thrombolysis in myocardial infarction frame count

CIMT and carotid plaque than patients with noexposure. It was reported by Caravedo et al.? that serum markers of endothelial inflammation such as ICAM-1, VCAM1 , and E-selection were significantly higher in BEG, which might suggest the role of inflammation in the presence of endothelial dysfunction in those patients. 
In our study, the WBC level was higher in the BEG than in the non-exposure group, suggesting enhanced inflammatory activity in that patient population. Fatmi et al. $^{23}$ conducted a study on women in Pakistan and found that cooking with BMF had a 4.8 fold increased risk of acute coronary syndrome when compared to the control group. In a cross-sectional observational study, the prevalence odds of HT were detected as increased 1.7 fold in BMF exposure patients. This increased risk was correlated with the duration of BMF use. ${ }^{9}$ HT prevalence was higher in the BEC than the control group in our study. Daily BMF inhalation was associated with altered echocardiographic parameters, including increased left atrial diameter, ventricular diastolic diameter, septal and lateral $E^{\prime}$ velocities, deteriorated left ventricular global longitudinal strain, systolic and diastolic biventricular dysfunction, and elevated pulmonary artery systolic pressure ${ }^{24,25}$. We did not compare all echocardiographic parameters in our research, but there was no significant difference regarding left ventricular ejection fraction between groups in our study.

The SCF is a well-known pathologic condition in which opacification of distal coronary vessels is delayed without any atherosclerotic lesion ${ }^{12}$. The underlying etiopathogenesis of SCF is still unclear. Endothelial dysfunction is considered one of the main causes of SCF. Arı et al. ${ }^{26}$ investigated the effect of endothelial dysfunction in patients with SCF, and they found that plasma asymmetric dimethylarginine levels were significantly higher and brachial artery endotheliumdependent flow-mediated dilatation was significantly lower in patients with SCF, which suggested the presence of endothelial dysfunction in patients with SCF. As mentioned above, biomass exposure leads to endothelial dysfunction, and this may explain the causative relationship of SCF with biomass exposure. Camsari et al. ${ }^{27}$ showed that the CIMT was significantly higher in patients with SCF than controls, which might support the SCF as being the result of subclinical coronary atherosclerosis. As noted before, the patients who had biomass exposure had higher CIMT than patients with no exposure, which might explain the underlying causal mechanism of the relationship between biomass exposure and SCF based on subclinical coronary atherosclerosis. Inflammation might be the other possible reason for SCF. Li et al. ${ }^{28}$ found that serum CRP and interleukin 6 levels were higher in patients with SCF than in controls. Barutcu et al. ${ }^{29}$ reported that patients with SCF had higher CRP levels than control patients, and serum CRP levels were correlated with TFC for each coronary artery. Canpolat et al. ${ }^{30}$ found in their research that WBC and CRP levels were higher in the SCF group, and both WBC and CRP were independent predictors of SCF. In accordance with these studies, our study showed that CRP and WBC levels were independently associated with the presence of SCF on coronary angiogram, which might suggest the role of inflammation in the development of SCF. Hawkins et al. ${ }^{31}$ investigated the clinical features of SCF and reported that patients with SCF had a higher BMI and that BMI was an independent predictor of the presence of SCF. Similarly, Yilmaz et al. ${ }^{32}$ found higher BMI levels in patients with SCF when compared to controls. In this study, we showed that BMI was independently associated with SCF. Yilmaz et al. ${ }^{32}$ reported that LDL cholesterol levels were higher in patients with SCF than in those without SCF. Our study revealed a similar result: LDL cholesterol was an independent predictor of SCF. Sanghvi et al. ${ }^{33}$ showed that patients with SCF had higher rates of $\mathrm{HT}$, and that the presence of HT was an independent predictor of the presence of SCF, which was similar in our study.

In the previous cohort studies, the prevalence of SCF was reported as being between $0.2 \%$ and $24 \%$ in patients with normal coronary arteries, which was in accordance with our non-exposure $\mathrm{arm}^{13}$. Diver et al. ${ }^{34}$ reported the prevalence of SCF as 34\% in their research. In contrast to our study, the patients in this study had unstabil angina pectoris with mild or moderate coronary artery stenosis, which might lead a higher occurence of SCF in that population. However, Arbel et al. ${ }^{35}$ showed a prevalence of $29.8 \%$ for SCF in patients with normal coronary arteries on angiogram in a population similar with our non-exposure arm. We detected the prevalence of SCF as $47.9 \%$ in the BEG in the current study. This might be explained by the causal link between SCF and biomass exposure especially with dried animal dung. Endothelial dysfunction, oxidative stress, and inflammation are considered as the main underlying pathologic mechanisms of the SCF phenomenon ${ }^{30}$. As mentioned before, we could conclude that BMF exposure might lead to the occurrence of endothelial dysfunction, endothelial inflammation, enhanced oxidative stress, and aggravated inflammation, all of which contributed to the higher prevalence of SCF in the BEG, especially in those who used dried animal dung ${ }^{1,4,7}$. The second explanation of a higher rate of SCF in the BEG might be that dried animal dung contained more PM, carbon monoxide, and sulfur dioxide than other fuels, including wood and leaves, agriculture residue, and also natural gas $^{6}$. It has been suggested that higher levels of PM and particulate concentration are related to an elevated risk of cardiovascular disease and non-fatal ischemic events $^{6,36}$. Additionally, higher PM pollution could lead 
to a significant increase in fibrinogen, platelet activation, plasma viscosity, and the release of endothelins, all of which played a role in the development of $\mathrm{SCF}^{13,36,37}$. Due to the leading heating and cooking material being dried animal dung in our study population, this more toxic material might lead to a higher prevalence of SCF in BEG in this study. Finally, the study was conducted on a population in a region with freezing and long winters. Women living in this region are intensely exposed to this type of fuel during the long winter season and while cooking all the day. This intense exposure may contribute to the existence of a high prevalence of SCF in this population.

Our study has a prominent clinical finding for patients who have been exposed to BMF inhalation. These patients have more frequent SCF, which is a risk factor for cardiovascular morbidity and mortality. The use of BMF in the world should be reduced as much as possible, and the use of other reliable fuel types should be provided. On the other hand, exposure to BMF inhalation should be kept in mind as a cardiovascular risk factor for atherosclerosis.

\section{Study Limitations}

The major limitations of this study were a retrospective study design and a small sample size. Another limitation was the inability to measure and quantify the amount of indoor air pollution. There might be possible unmeasured confounders that were related to SCF in this study. The lack of a comparison of the other echocardiographic parameters other than ejection fraction was another limitation. The study was conducted on patients who had used dried animal dung as a BMF in a regional area. So, the results of this study could not be generalized to the other regions, especially in the areas those using other biomass fuels for cooking and heating. Although the study area was free from industrial pollution, the effect of outdoor pollution was not taken into account. Due to a retrospective study design, the time of exposure to BMF inhalation was noted according to the information given by patients. Thus, prospective cross-sectional studies with a larger sample size might provide more information about the effect of BMF exposure on the presence of SCF.

\section{CONCLUSIONS}

This study confirms that indoor biomass exposure due to dried animal dung is harmful to the cardiovascular system by causing SCF phenomenon and subclinical cardiovascular damage in the female population.

\section{Ethics}

Ethics Committee Approval: The Van Training and Research Hospital Clinical Research Ethics Committee approved the study, and the research was done in accordance with the Declaration of Helsinki (decision no: 2020/20, date: 08.10.2020).

Informed Consent: Retrospective study.

Peer-review: Externally and internally peerreviewed.

\section{Author Contributions}

Concept: T.A., F.S., Design: T.A., F.S., Data Collection and/or Processing: T.A., F.S., Analysis and/or Interpretation: F.S., Critical Revision: T.A., F.S., Writing: F.S.,

Conflict of Interest: The authors have no conflict of interest to declare.

Financial Disclosure: The authors declared that this study has received no financial support.

\section{REFERENCES}

1. Buturak A, Genç A, Ulus OS, Duygu E, Okmen AS, Uyarel H. Evaluation of the effects of chronic biomass fuel smoke exposure on peripheral endothelial functions: an observational study. Anadolu Kardiyol Derg. 2011;11:492-7.

2. Alim MA, Sarker MA, Selim S, Karim MR, Yoshida Y, Hamajima N Respiratory involvements among women exposed to the smoke of traditional biomass fuel and gas fuel in a district of Bangladesh. Environ Health Prev Med. 2014;19:126-34.

3. Dutta A, Mukherjee B, Das D, Banerjee A, Ray MR. Hypertension with elevated levels of oxidized low-density lipoprotein and anticardiolipin antibody in the circulation of premenopausal Indian women chronically exposed to biomass smoke during cooking. Indoor Air. 2011;21:165-76.

4. Dutta A, Ray MR, Banerjee A. Systemic inflammatory changes and increased oxidative stress in rural Indian women cooking with biomass fuels. Toxicology Appl Pharmacol. 2012;261:255-62.

5. McCracken J, Smith KR, Stone P, Díaz A, Arana B, Schwartz J. Intervention to Lower Household Wood Smoke Exposure in Guatemala Reduces ST-Segment Depression on Electrocardiograms. Environ Health Perspect. 2011;119:1562-8.

6. Kim KH, Jahan SA, Kabir E. A review of diseases associated with household air pollution due to the use of biomass fuels. J Hazar Mater. 2011;192:425-31.

7. Caravedo MA, Herrera PM, Mongilardi N, et al. Chronic exposure to biomass fuel smoke and markers of endothelial inflammation. Indoor Air. 2016;26:768-75.

8. Burroughs Peña M, Romero KM, Velazquez EJ, et al. Relationship Between Daily Exposure to Biomass Fuel Smoke and Blood Pressure in High-Altitude Peru. Hypertension. 2015;65:1134-40.

9. Lee MS, Hang JQ Zhang FY, Dai HL, Su L, Christiani DC. In-home solid fuel use and cardiovascular disease: a cross-sectional analysis of the Shanghai Putuo study. Environ Health. 2012;11:18. 
10. Juntarawijit C, Juntarawijit Y. Cooking with biomass fuel and cardiovascular disease: a cross-sectional study among rural villagers in Phitsanulok, Thailand. F1000Res 2020;9:307.

11. McCracken JP, Wellenius GA, Bloomfield GS, et al. Household Air Pollution from Solid Fuel Use: Evidence for Links to CVD. Glob Heart. 2012;7:223-34.

12. Tambe AA, Demany MA, Zimmerman HA, Mascarenhas E. Angina pectoris and slow flow velocity of dye in coronary arteries--A new angiographic finding. Am Heart J. 1972;84:66-71.

13. Chalikias G, Tziakas D. Slow Coronary Flow: Pathophysiology, Clinical Implications, and Therapeutic Management. Angiology. 2021;72:808-18.

14. Beltrame JF, Limaye SB, Horowitz JD. The Coronary Slow Flow Phenomenon -- A New Coronary Microvascular Disorder. Cardiology. 2002;97:197-202.

15. Shui Z, Wang Y, Sun M, et al. The effect of coronary slow flow on left atrial structure and function. Sci Rep. 2021;11:7511.

16. Amasyali B, Turhan $H$, Kose $S$, et al. Aborted sudden cardiac death in a 20-year-old man with slow coronary flow. Int J Cardiol. 2006;109:427-9.

17. Saya S, Hennebry TA, Lozano P, Lazzara R, Schechter E. Coronary Slow Flow Phenomenon and Risk for Sudden Cardiac Death Due to Ventricular Arrhythmias: A Case Report and Review of Literature. Clin Cardiol. 2008;31:352-5.

18. Gibson CM, Cannon CP, Daley WL, et al. TIMI frame count: a quantitative method of assessing coronary artery flow. Circulation. 1996;93:879-88.

19. Bonjour S, Adair-Rohani H, Wolf J, et al. Solid Fuel Use for Household Cooking: Country and Regional Estimates for 19802010. Environ Health Perspect. 2013;121:784-90.

20. World Health Organization. Household air pollution; 2021. Available from: https://www.who.int/health-topics/air-pollution \#tab=tab_3

21. Brook RD, Rajagopalan S, Pope CA, et al. Particulate Matter Air Pollution and Cardiovascular Disease. Circulation 2010;121:2331-78.

22. Painschab MS, Davila-Roman VG, Gilman RH, et al. Chronic exposure to biomass fuel is associated with increased carotid artery intima-media thickness and a higher prevalence of atherosclerotic plaque. Heart. 2013;99:984-91.

23. Fatmi Z, Sahito A, Ntani G, Coggon D. Acute coronary syndrome and use of biomass fuel among women in rural Pakistan: a casecontrol study. Int J Public Health. 2020;65:149-57.

24. Burroughs Peña MS, Velazquez EJ, Rivera JD, et al. Biomass fuel smoke exposure was associated with adverse cardiac remodeling and left ventricular dysfunction in Peru. Indoor Air. 2017;27:73745.
25. Kargin R, Kargin F, Mutlu H, et al. Long-Term Exposure to Biomass Fuel and Its Relation to Systolic and Diastolic Biventricular Performance in Addition to Obstructive and Restrictive Lung Diseases. Echocardiography. 2011;28:52-61.

26. Arı H, Arı S, Erdoğan E, et al. The effects of endothelial dysfunction and inflammation on slow coronary flow. Turk Kardiyol Dern Ars. 2010;38:327-33.

27. Camsari A, Ozcan T, Ozer C, Akcay B. Carotid artery intima-media thickness correlates with intravascular ultrasound parameters in patients with slow coronary flow. Atherosclerosis. 2008;200:3104.

28. Li JJ, Qin XW, Li ZC, et al. Increased plasma C-reactive protein and interleukin- 6 concentrations in patients with slow coronary flow. Clin Chim Acta. 2007;385:43-7.

29. Barutcu I, Sezgin AT, Sezgin N, et al. Increased High Sensitive CRP Level and Its Significance in Pathogenesis of Slow Coronary Flow. Angiology. 2007; 58:401-7.

30. Canpolat U, Çetin EH, Cetin S, et al. Association of Monocyteto-HDL Cholesterol Ratio with Slow Coronary Flow is Linked to Systemic Inflammation. Clin Appl Thromb Hemost. 2015;22:47682.

31. Hawkins BM, Stavrakis S, Rousan TA, Abu-Fadel M, Schechter E. Coronary Slow Flow - Prevalence and Clinical Correlations. Circ J. 2012;76:936-42.

32. Yilmaz H, Demir I, Uyar Z. Clinical and coronary angiographic characteristics of patients with coronary slow flow. Acta Cardiol. 2008;63:579-84.

33. Sanghvi S, Mathur R, Baroopal A, Kumar A. Clinical, demographic, risk factor and angiographic profile of coronary slow flow phenomenon: A single centre experience. Indian Heart J. 2018;70(Suppl 3):290-4.

34. Diver DJ, Bier JD, Ferreira PE, et al. Clinical and arteriographic characterization of patients with unstable angina without critical coronary arterial narrowing (from the TIMI-IIIA trial). Am J Cardiol. 1994;74:531-7.

35. Arbel $Y$, Rind E, Banai S, et al. Prevalence and predictors of slow flow in angiographically normal coronary arteries. Clin Hemorheol Microcirc. 2012;52:5-14.

36. Brook RD, Franklin B, Cascio W, et al. Air pollution and cardiovascular disease: a statement for healthcare professionals from the Expert Panel on Population and Prevention Science of the American Heart Association. Circulation. 2004;109:2655-71.

37. Indrajaya T, Ghanie A, Arman A. Accuracy of Fibrinogen/Ddimer Ratio in Predicting the Occurrence of Coronary Slow Flow Phenomenon. Open Access Macedonian Journal of Medical Sciences. 2020;8:1229-33. 